\title{
An evaluation of biosecurity compliance levels and assessment of associated risk factors for Highly Pathogenic Avian Influenza H5N1 infection of Live-Bird-Markets, Nigeria and Egypt
}

Olubunmi G. Fasanmi ${ }^{1,2, *}$, Syed Sayeem U. Ahmed ${ }^{3}$, Mutiu O. Oladele-Bukola ${ }^{4}$, Abdelgawad S. El-Tahawy $^{5}$, Ahmed R. Elbestawy ${ }^{6}$, Folorunso O. Fasina ${ }^{7}$

${ }^{1}$ Department of Production Animal Studies, Faculty of Veterinary Science, University of Pretoria,

South, Africa

${ }^{2}$ Department of Animal Health, Federal College of Animal Health and Production Technology,

Ibadan, Nigeria

3 Department of Epidemiology and Public Health, Faculty of Veterinary and Animal Science, Sylhet

Agricultural University, Sylhet, Bangladesh

${ }^{4}$ Institute of Agriculture Research and Training, Obafemi Awolowo University, Moor Plantation, Ibadan, Nigeria.

${ }^{5}$ Department of Animal Husbandry and Wealth Development, Faculty of Veterinary Medicine, Damanhour University, Egypt.

${ }^{6}$ Department of Poultry and Fish Diseases, Faculty of Veterinary Medicine, Damanhour University, Egypt. 
${ }^{7}$ Department of Veterinary Tropical Diseases, University of Pretoria, Onderstepoort 0110, South Africa.

*Corresponding author: Dr. Olubunmi G. Fasanmi, Department of Production Animal Studies, Faculty of Veterinary Science, University of Pretoria, Onderstepoort 0110, South Africa; E mail: bumaetal@gmail.com; Phone number: +27625047537 


\section{Graphical Abstract}
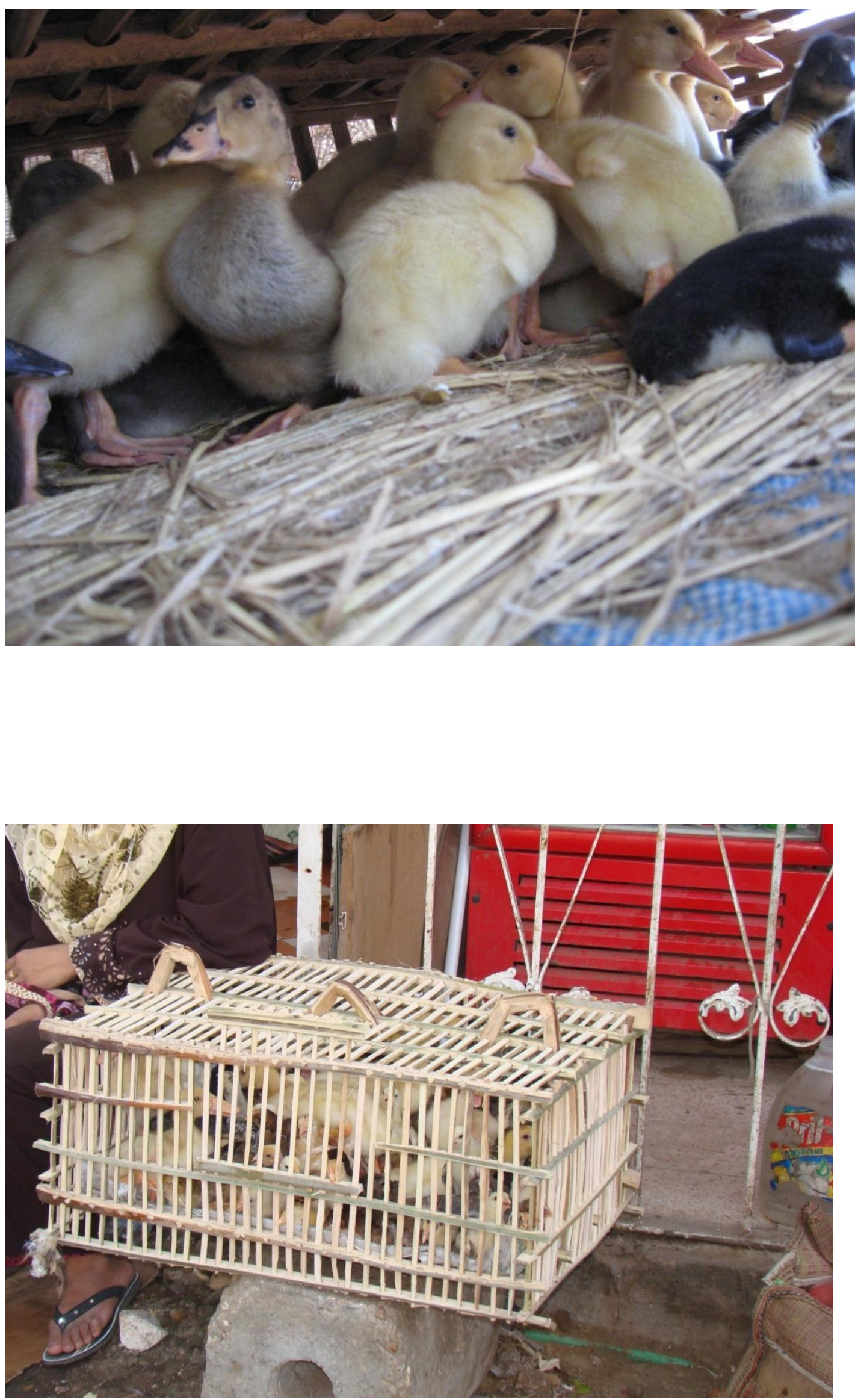


\section{Highlights:}

- The administration of a 68-item biosecurity checklist was done at LBMs in Nigeria and Egypt, scored and analysed for risk factors for HPAI H5N1

- $\quad$ No surveyed live bird markets in Nigeria and Egypt qualify for $100 \%$ biosecurity compliance and risky behaviour predominates.

- Wild animals trade in the LBMs was a risk factor and routine disinfection of LBMs, hand washing after slaughter and traceability were protective factors

- Participatory approach, multidisciplinary team and innovative government intervention will stop continued spread of HPAI H5N1. 


\begin{abstract}
Live bird market (LBM) is integral component in the perpetuation of HPAI H5N1, while biosecurity is crucial and key to the prevention and control of infectious diseases. Biosecurity compliance level and risk factor assessments in 155 LBMs was evaluated in Nigeria and Egypt through the administration of a 68-item biosecurity checklist, scored based on the modifications of previous qualitative data, and analysed for degree of compliance. LBMs were scored as "complied with a biosecurity item" if they had good-very good scores (4). All scores were coded and analysed using descriptive statistics and risk or protective factors were determined using univariable and multivariable logistic regression at $p \leq 0.05$. Trading of wild birds and other animal in the LBMs (Odd Ratio $(\mathrm{OR})=34.90 ; p=0.01)$ and claims of hand disinfection after slaughter $(\mathrm{OR}=31.16 ; p=0.03)$ were significant risk factors while mandatory routine disinfection of markets $(\mathrm{OR}=0.13 ; p \leq 0.00)$, fencing and gates for live bird market $(\mathrm{OR}=0.02 ; p \leq 0.01)$ and hand washing after slaughter $(\mathrm{OR}=$ $0.41 ; p \leq 0.05)$ were protective factors for and against the infection of Nigerian and Egyptian LBMs with the HPAI H5N1 virus. Almost all the LBMs complied poorly with most of the variables in the checklist $(p \leq 0.05)$, but pathways to improved biosecurity in the LBMs existed. We concluded that the LBM operators play a critical role in the disruption of transmission of $\mathrm{H} 5 \mathrm{~N} 1$ virus infection through improved biosecurity and participatory epidemiology and multidisciplinary approach is needed.
\end{abstract}

Key words: Biosecurity compliance; HPAI H5N1; Live-Bird-Markets; Risk factors 


\section{Introduction}

Highly pathogenic avian influenza (HPAI) H5N1 remains an emerging zoonotic disease with significant economic, food security and human health impacts (Brown et al., 2015). The first outbreak of HPAI H5N1 in Africa was in Kaduna, Nigeria in February 2006 (Joanis et al., 2006), with consequent destruction of millions of poultry and approximately US\$ 5.4 million paid in compensation by the Government of Nigeria. Subsequently, outbreaks have been reported in 11 other African countries (OIE, 2015; FAO, 2015). Proportions of the H5N1 positive samples in Nigeria ( $\mathrm{n}=$ 12) and Egypt $(n=152)$ were market-based or have had links with the live bird markets (LBMs) (Joannis et al., 2008). Whereas HPAI H5N1 has become endemic in Egypt, its resurgence in recent times have been reported in five African countries and Nigeria continues to report outbreaks in 2016 (OIE, 2016). While farm-based risk factor analyses and evaluation of biosecurity has been made with regard to HPAI H5N1 in poultry in Africa (Fasina et al., 2011; Metras et al., 2012; Sheta et al., 2014), market-level evaluation remain largely unexplored. However, previous studies in Asia have confirmed that LBMs played major roles in the introduction, transmission and maintenance in circulation of influenza viruses (Kung et al., 2003; Webster, 2004; Wang et al., 2006; Indriani et al., 2010; Wan et al., 2011; Zhou et al., 2015).

LBMs are suitable vehicles for the rapid dissemination of influenza viruses (including but not limited to H5N1) because of the central role they play in product distributions and the many trade links they have with farms, roads, abattoirs, slaughter slabs, households and many other locations. Patterns of spread have been associated with uncontrolled movement of poultry and poultry products, lack of effective contingency plan to guide the containment, geographical and ecological factors (Rivas et al., 2010; FAO, 2015).

Pagani et al (2008) have earlier recommended the implementation of strict biosecurity measures in Nigerian LBMs to prevent or reduce the risk of infections or disease in poultry operations. Partially implemented and ineffective measures may create conditions that favour the spread of disease agents within the poultry sector (Yupiana et al., 2010). This study therefore seeks to assess the level of 
biosecurity compliance and the associated risks of non-compliance and to identify factors that can potentially influence the introduction and spread of HPAI H5N1 in the Nigerian and Egyptian LBMs, the study was conducted in LBMs in Nigeria and Egypt, and this is the report of the findings.

\section{Materials and methods}

\section{Checklist development and identification of Live bird markets}

During the HPAI H5N1 outbreak of 2006-2008 in Nigeria, outbreaks were recorded from farms; live bird markets (LBMs), zoos and other locations. Because of the central roles of LBMs and their implications in the dissemination of HPAI H5N1 in Nigeria through trade, expert epidemiologists were recruited to qualitatively assess the LBMs (Pagani et al., 2008; Anonymous, 2008). The documents were reviewed with regard to areas suggested for improvement of biosecurity t the LBMs. A comprehensive checklist was developed based on these three criteria: (i) formulated policies and regulations, (ii) facilities at the LBMs, and (iii) tools and equipments at the LBMs. A total of 68 variables were identified and included in the checklist after the removal of duplicates and these were arranged based on the three criteria previously stated to determine and evaluate the level of compliance (Supplementary Table 1).

Based on the density of LBMs in South-west Nigeria and the geographical spread, a total of 75 influential markets (popular markets with high traffic and turnout of poultry and also patronage) were selected including 24 weekly and 51 daily LBMs randomly distributed within the urban and peri-

urban/rural areas of six states. The daily and weekly LBMs have previously been described (Pagani et al., 2008; Fasina et al., 2016), and the pretested checklist was used to obtain detailed data in these LBMs. One to two (1-2) questionnaires were administered to respondents per live bird market depending on the size of the market. Respondent were selected based on the fact that they are live bird sellers in the market and fulfil the inclusion criteria of being active as at the time of selection and having been involved in poultry sale for at least five years. The LBMs were selected randomly and at least 10 questionnaires were administered per state. At the time of planning of survey, the northern 
part of the country was included but was technically difficult to access some parts of northern Nigeria in view of on-going insurgency and because the dynamics of poultry movements, trade and distributions favours the South-west Nigeria LBMs, it was expected that these samples should be representative. (the sampled LBMs in south western Nigeria).

In Egypt, LBMs were selected from five contiguous governorates based on geographic features, trade volumes and human-animal densities rather than outbreak reports (El Masry et al., 2015), because Egypt has been declared to be endemically infected with HPAI H5N1 in poultry. Random surveillance reports have identified outbreaks in many of these locations, hence daily and weekly LBMs in Alexandria, Beheira, Kafr El Sheik, Menofyia and Gharbia governorates were randomly selected. The 68 item biosecurity checklists were designed and administered in Arabic in the 80 LBMs in all the five governorates. The questionnaires were translated and administered by trained interviewers (veterinarians and animal health personnels). Informed oral consent (permission) was sought prior to interviews, and at the conclusion of each interview; the completed questionnaires were reviewed by

the authors for missing, unclear, or inconsistent responses. A total of 155 questionnaires were administered in all the LBMs in Nigeria and Egypt

\section{Infected LBMs (positive and negative LBM)}

The LBMs were confirmed as positive or negative based on the protocol description of Joannis et al., (2008). Briefly, following suspicion of an infection or outbreak of HPAI H5N1 in poultry at the LBM, a team was sent to assess the outbreak and collect samples (tracheal and cloacal swabs,

parenchymatous tissues and sera) from post-mortem carcasses, moribund or freshly killed birds. Collected samples were dispatched to the central laboratory where virus isolation on embryonated chicken eggs and haemagglutination-inhibition (HI) tests were conducted to determine the virus subtype. In parallel, viral RNA extraction and reverse transcription-polymerase chain reaction (RTPCR) were carried out on tissue or other samples as described (Joannis et al., 2006). All negative allantoic fluids on virus isolation were passaged in a second set of embryonated chicken eggs and any 
samples negative after the second passage was declared negative. For sera, serological assays were done using agar-gel immune-diffusion test (AGID) test using the H5 antigen (Joannis et al., 2006).

An LBM was said to be positive, if any of the above test (RT-PCR and or virus isolation, in addition to serology) confirmed an $\mathrm{H} 5 \mathrm{~N} 1$ virus or genetic material. Where such a positive confirmation could not be established, the LBM was declared as negative.

\section{Study Design and scoring of the checklist}

All selected LBMs in Nigeria and Egypt were visited between February and May 2015 (Fig 1a \& b). The 68-item self-rated biosecurity checklist was scored in the following way: observed biosecurity compliance level is non-existent to very poor $(0-25 \%=1)$; very poor to poor $(26-50 \%=2)$; poor to good $(51-75 \%=3)$ and good to very good $(\geq 75 \%=4)$. These scores were based on the modification of the qualitative scores given by Pagani et al., (2008). For any item to be scored as "being complied with", it must obtain a score of " 4 ", and for the purpose of statistical analysis, all score below " 4 " that is (1-3) were made equal to 0 , while scores greater than or equal to "4" was assigned a score of 1 . A complete list of the items is available in Tables 1, 2, 3 and Supplementary Table 1.

\section{Statistical analyses}

All scores were entered into Microsoft Excel@ (Microsoft Redmond, USA) and translated into codes suitable for analyses in the Intercooled Stata 9.0 for Windows (StataCorp, College Station, Texas, USA), and analyzed using descriptive statistical program for proportions. The dichotomic data were also subjected to logistic regression to model the odds of being an HPAI H5N1 case as a function of investigated adherence or lack thereof of the biosecurity factors. Initial screening of potential risk factors for HPAI H5N1 infection was performed by use of univariable logistic regression (Hosmer and Lemeshow, 1989). Co-linearity of the independent variables and interaction among them were checked during the model building process using Tolerance and Variance Inflation Factor (VIF) as 

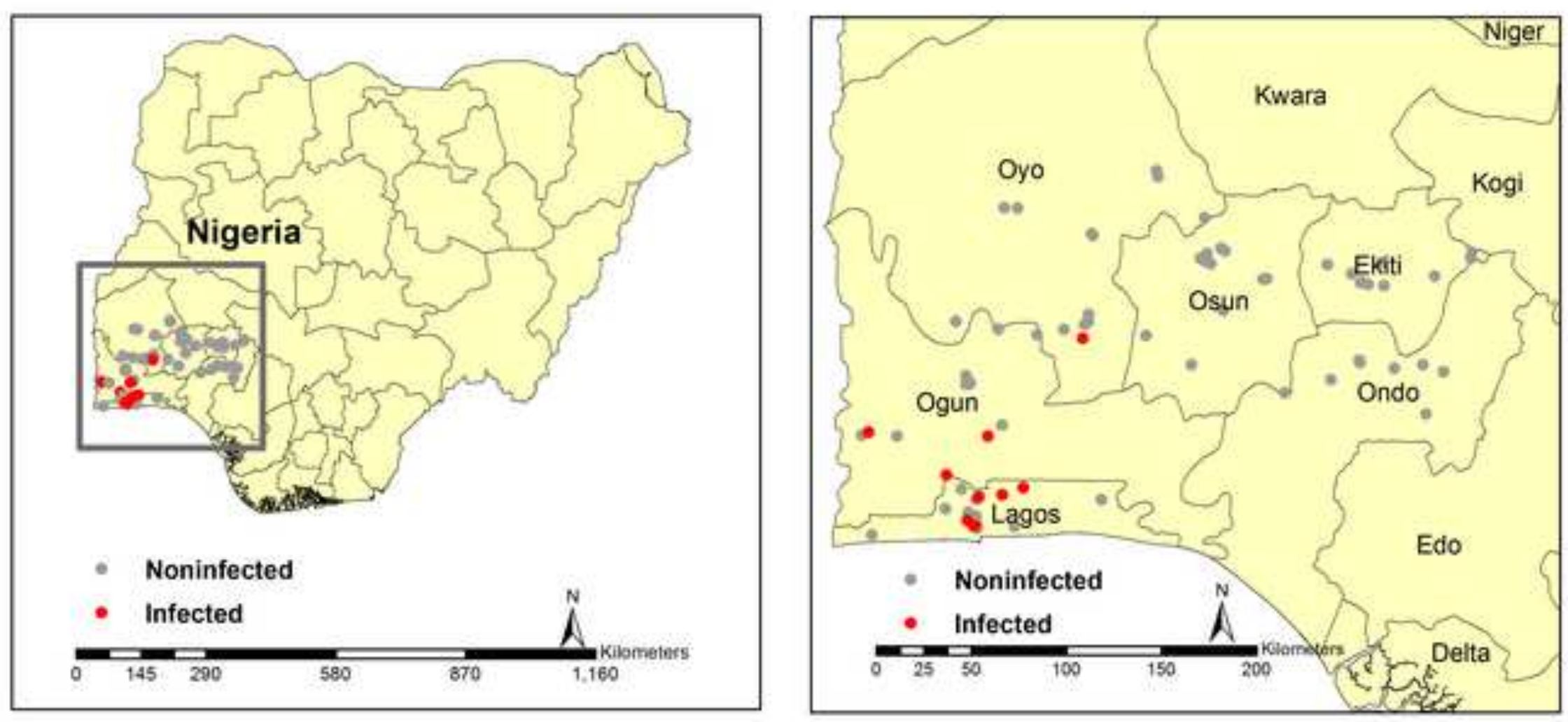

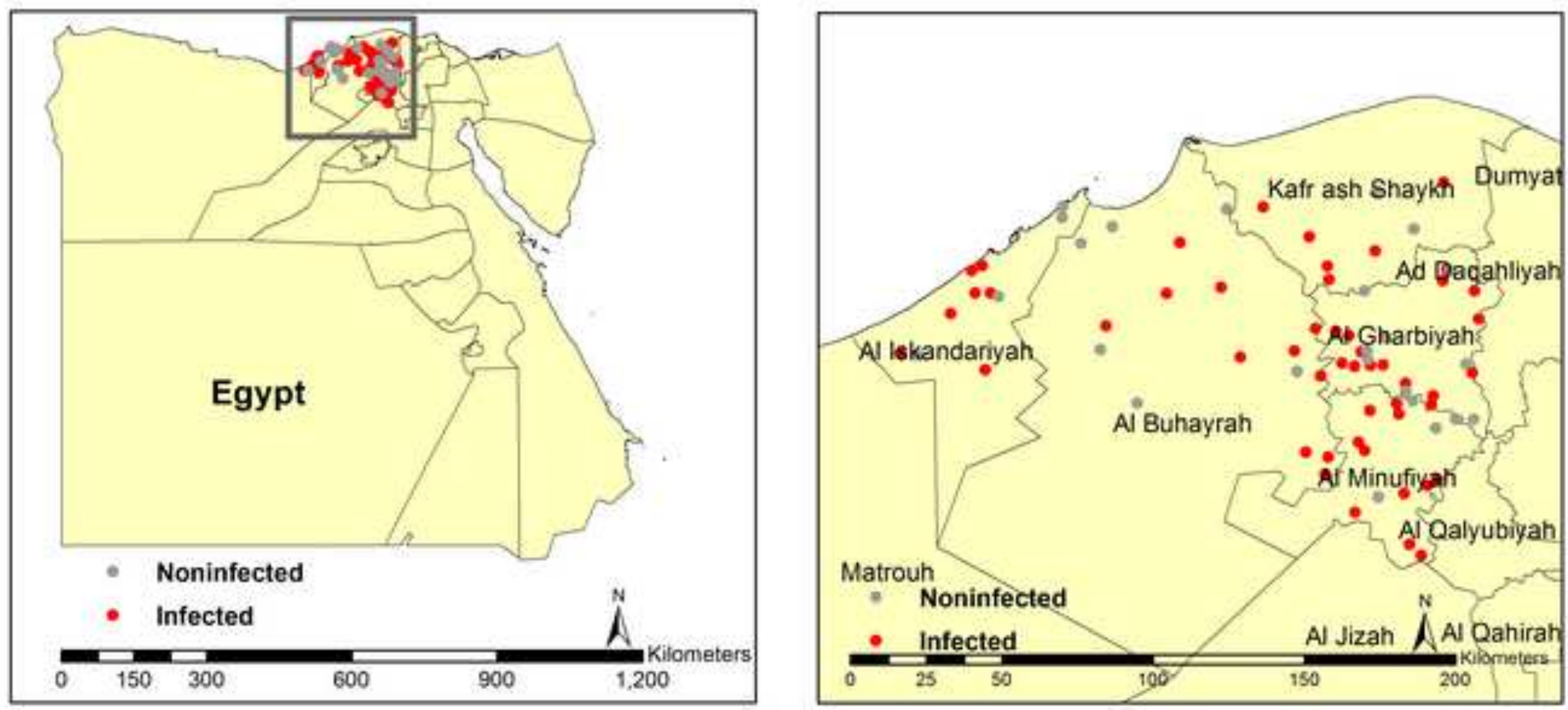

Figure 1 (a) Map of Nigeria showing the locations of sampled LBMs (b)Map of Egypt showing the locations of sampled LBMs. 
diagnostic. No significant interaction was observed and for the co-linearity, a Tolerance level of 0.3 and a corresponding VIF of 3.33 were set as cut -off for considering instability posed by co-linearity in the model. Variables associated $(\mathrm{P} \leq 0.20)$ with the outcome of interes $\mathrm{t}$ were considered for inclusion in a multivariable logistic regression analysis. Associations between exposure variables $(\mathrm{P} \leq$ $0.20)$ were examined and when a pair of variables was associated $\left(\mathrm{P} \leq 0.05\right.$ by use of a $\chi^{2}$ test, two tailed), the exposure variable judged as most biologically plausible was used as a candidate in the multivariable logistic regression analysis. A backward stepwise approach was used to identify variables associated with infection by use of a 2 -sided P-values-to-enter and P-values-to-remove of 0.05 and 0.10 respectively. Values for the final model were considered as significant at $\mathrm{P} \leq 0.05$. Fit of the model to the data was assessed by a visual examination of residual plots (standardised $\Delta$ - $\beta$ values versus observation number and $\Delta$ - $\beta$ vs fitted values). Case-control sets that had LBMs with extreme $\Delta$ - $_{\beta}$ values and low fitted values were excluded from the analysis to evaluate their influence on estimated odd ratios. In the final model, the adjusted odd ratios (OR) and 95\% confidence interval (CI) were reported.

\section{Results}

The overall results show that no single LBM passed the entire 68 -item checklist in the surveyed locations and no significant difference obtained between the peri-urban/rural and urban markets. However between the daily and weekly markets, some differences in compliance levels were seen and these are documented in Figure 2. The weekly LBMs performed better than the daily LBMs ( $\mathrm{p}<$ $0.05)$. 


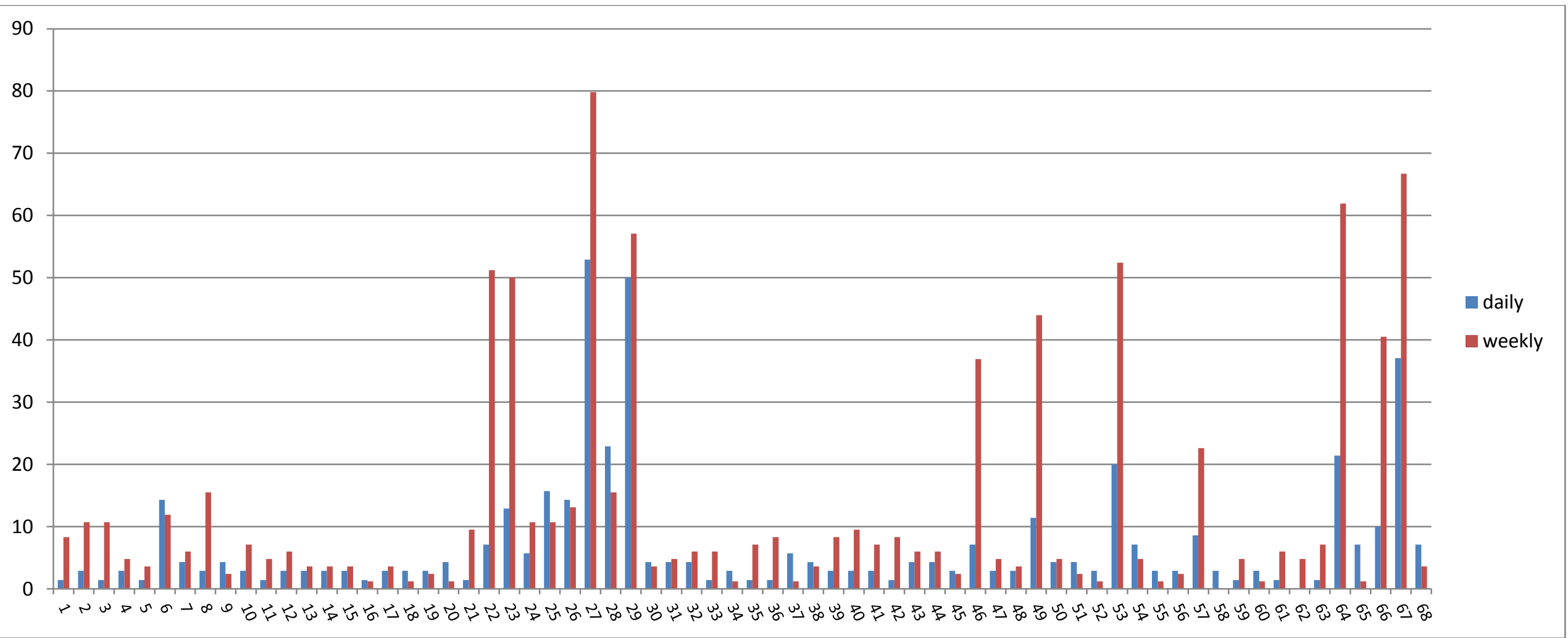

1. Monitor activities in the market; 2. Document movement of poultry into or from the market; 3. Control movement of poultry into or from the market; 4. Availability of specifications for vehicles carrying birds; 5. Formal training of operators; 6. Location of market is appropriate to prevent/reduce human contacts; 7 . Fencing and gates around the market; 8 . Poultry market separated from other stands; 9. Ante and post-mortem inspection of birds; 10. Access to para-veterinary services; 11. Access to veterinary inputs; 12 . Garbage disposal services; 13. All in-all out policy in the market; 14. Segregation of customers and birds; 15. Availability of cold chain; 16. Quarantine for sick birds; 17. Facilities for culling birds; 18. Presence of a laboratory in the LBM; 19. Presence of an incinerator in the LBM; 20. Disinfection facilities for trucks; 21 . Reduce density for birds in cages; 22 . Active poultry sellers association; 23. Separation of birds by species; 24. Separation of birds by age/class; 25. Control presence of wild birds; 26. Control presence of pests; 27. Other animals traded in the market; 28 . Wild animals traded in the market; 29. Mandatory routine disinfections of the market; 30. Restriction of movement of operators from market to market; 31 . Floor and walls are easy to clean; 32. Presence of drains on the floor; 33. Availability of clean water; 34. Availability of hot water; 35. Availability of toilets; 36. Access to facility to wash hands and shoes; 37. Access to facility to disinfect hands and shoes; 38. Safe disposal of sick birds; 39. Safe disposal of carcasses; 40. Safe disposal of wastes; 41 . Good hygiene in the market; 42. Good hygiene at slaughtering points; 43. Disinfection of infrastructure and equipment; 44. Disinfection of premises; 45. Alternative use of disinfectants; 46. Compensation mechanism in place for culled birds; 47. Availability of storage facilities; 48. Keeping of new arrivals separated from old stock; 49. Enclosure to prevent escape; 50 . Improved cages present in the market; 51 . Water delivery system in place in the market; 52. Food delivery system in place in the market; 53. Cleaning of cages done routinely; 54. Disinfection of cages done routinely; 55. Prohibition of sharing of cages and other equipment; 56. Disinfection of shared equipments; 57. Traceability of origin of birds being sold; 58 . Certification system in place for transport of birds; 59. Rest period between batches of birds; 60. Policy is in place for unsold birds; 61. Availability of processing facilities; 62. Live in-dead out policy is in place; 63. Improved packaging of slaughtered birds; 64. Cleaning of equipments used for slaughtering; 65. Disinfection of equipments used for slaughtering; 66. Protective materials worn by slaughter/processing persons; 67. Hands washing after slaughter; 68. Hands disinfection after slaughter.

Figure 2. Graphical comparison of biosecurity compliance level of daily and weekly LBMs 


\section{Compliance with policy and regulation-related biosecurity}

Almost all of the items under policy and regulation-related biosecurity compliance were poor in all the LBMs in Nigeria and Egypt. Based on comparison between the two countries for adherence to biosecurity, it was observed that compliance levels on documentation of movement of poultry into or from the market $(P=0.02)$, control of movement of poultry into or from the market $(P=0.04)$, active

poultry sellers' association $(P<0.0001)$, separation of birds by species $(P=0.05)$, compensation mechanism in place for culled birds $(P=0.001)$, traceability of origin of birds being sold $(P=0.03)$, hands washing after slaughter $(P<0.0001)$ and claims of hands disinfection after slaughter $(P=$ 0.005) were significantly better in Nigeria than Egypt (Table 1). However, Egypt performed significantly better in compliance with control of presence of wild birds $(P<0.0001)$, control of presence of pests $(P<0.0001)$, less other non-avian animals traded in the market $(P<0.0001)$, less wild animals traded in the market $(P<0.0001)$, mandatory routine disinfections of the markets $(P<$ $0.0001)$ and alternative use of disinfectants in the markets $(P=0.05)$. All other parameters, such as monitoring of activities, specification of vehicle for transporting birds, formal training of operators, safe disposal of sick birds, good hygiene in the LBMs, live in dead out policy in place, are not significantly different among the LBMs in both countries (Table 1).

\section{Compliance with facility-related biosecurity}

Generally, the result for the various biosecurity parameters in the LBMs for both countries show very low level of compliance but Egypt LBMs performed significantly better in compliance with appropriateness of location of the LBM to prevent human contacts $(P<0.01)$, disinfection facilities for trucks $(P=0.05)$ and access to facility to disinfect hands and shoes $(\mathrm{P}=0.03)$ (Table 2$)$. 
Table 1. Policy and regulation-related biosecurity

\begin{tabular}{|c|c|c|c|c|c|}
\hline s/no. & Policy and regulation-related biosecurity checklists & $\begin{array}{c}\text { Broad overview } \\
\text { of compliance at } \\
\text { LBM levels, } \\
\text { Nigeria* }\end{array}$ & $\begin{array}{l}\text { Nigerian LBM Compliance } \\
\text { level } \pm \text { SE }(\%)^{* *}\end{array}$ & $\begin{array}{c}\text { Egyptian LBM Compliance } \\
\text { level } \pm \text { SE }(\%)^{* *}\end{array}$ & P-value \\
\hline 1 & Monitor activities in the market & Poor & $8.1 \pm 3.2$ & $2.5 \pm 1.7$ & 0.12 \\
\hline 2 & Document movement of poultry into or from the market & Poor & $12.2 \pm 3.8$ & $2.5 \pm 1.7$ & 0.02 \\
\hline 3 & Control movement of poultry into or from the market & Very poor & $10.8 \pm 3.6$ & $2.5 \pm 1.7$ & 0.04 \\
\hline 4 & Availability of specifications for vehicles carrying birds & Poor & $4.1 \pm 2.3$ & $3.8 \pm 2.1$ & 0.94 \\
\hline 5 & Formal training of operators & Poor & $2.7 \pm 1.9$ & $2.5 \pm 1.7$ & 0.95 \\
\hline 6 & Ante and post-mortem inspection of birds & Very poor & $2.7 \pm 1.9$ & $3.8 \pm 2.1$ & 0.7 \\
\hline 7 & Access to para-veterinary services & Good & $8.1 \pm 3.2$ & $2.5 \pm 1.7$ & 0.12 \\
\hline 8 & Access to veterinary inputs & Good & $5.4 \pm 2.7$ & $1.3 \pm 1.3$ & 0.15 \\
\hline 9 & All in-all out policy in the market & Very poor & $2.7 \pm 1.9$ & $3.8 \pm 2.1$ & 0.7 \\
\hline 10 & Active poultry sellers association & Good & $48.7 \pm 5.9$ & $15 \pm 4.0$ & $<0.0001$ \\
\hline 11 & Separation of birds by species & Very poor & $40.5 \pm 5.8$ & $26.3 \pm 5.0$ & 0.05 \\
\hline 12 & Separation of birds by age/class & Poor-good & $9.5 \pm 3.4$ & $7.5 \pm 3.0$ & 0.68 \\
\hline 13 & Control presence of wild birds & Very poor & $1.4 \pm 1.4$ & $23.8 \pm 4.8$ & $<0.0001$ \\
\hline 14 & Control presence of pests & Very poor & $4.1 \pm 2.3$ & $22.5 \pm 4.7$ & $<0.0001$ \\
\hline 15 & Other animals traded in the market & Poor & $96.0 \pm 2.3$ & $41.3 \pm 5.5$ & $<0.0001$ \\
\hline 16 & Wild animals traded in the market & Poor-good & $74.3 \pm 5.1$ & $35.0 \pm 5.4$ & $<0.0001$ \\
\hline 17 & Mandatory routine disinfections of the market & Poor-good & $2.7 \pm 1.9$ & $33.8 \pm 5.3$ & $<0.0001$ \\
\hline 18 & Restriction of movement of operations from market to market & Poor & $2.7 \pm 1.9$ & $5.0 \pm 2.5$ & 0.45 \\
\hline 19 & Safe disposal of sick birds & Very poor & $2.7 \pm 1.9$ & $5.0 \pm 2.5$ & 0.45 \\
\hline 20 & Safe disposal of carcasses & Very poor-good & $6.8 \pm 2.9$ & $5.0 \pm 2.5$ & 0.66 \\
\hline 21 & Safe disposal of wastes & poor-good & $8.1 \pm 3.2$ & $5.0 \pm 2.5$ & 0.45 \\
\hline 22 & Good hygiene (proper cleaning and disinfection) in the market & Very poor & $5.4 \pm 2.7$ & $5.0 \pm 2.5$ & 0.93 \\
\hline 23 & $\begin{array}{l}\text { Good hygiene (proper cleaning and disinfection) at slaughtering } \\
\text { points }\end{array}$ & Very poor & $6.8 \pm 2.9$ & $3.8 \pm 2.1$ & 0.41 \\
\hline 24 & Disinfection of infrastructure and equipment & Poor-good & $4.1 \pm 2.3$ & $6.3 \pm 2.7$ & 0.53 \\
\hline 25 & Disinfection of premises & Poor & $4.1 \pm 2.3$ & $6.3 \pm 2.7$ & 0.53 \\
\hline 26 & Alternative use of disinfectants & Poor-good & 0 & $5.0 \pm 2.5$ & 0.05 \\
\hline 27 & Compensation mechanism in place for culled birds & Poor & $35.1 \pm 5.6$ & $12.5 \pm 3.7$ & 0.001 \\
\hline 28 & Keeping of new arrivals separated from old stock & Poor-good & $2.7 \pm 1.9$ & $3.8 \pm 2.1$ & 0.7 \\
\hline 29 & Prohibition of sharing of cages and other equipment & Good & 0 & $3.8 \pm 2.1$ & 0.09 \\
\hline 30 & Traceability of origin of birds being sold & Poor-good & $23.0 \pm 4.9$ & $10.0 \pm 3.4$ & 0.03 \\
\hline 31 & Certification system in place for transport of birds & Poor & 0 & $2.5 \pm 1.8$ & 0.17 \\
\hline 32 & Rest period between batches of birds & Very poor & $4.1 \pm 2.3$ & $2.5 \pm 1.8$ & 0.58 \\
\hline 33 & Policy is in place for unsold birds & Very poor-good & 0 & $3.8 \pm 2.1$ & 0.09 \\
\hline 34 & Live in-dead out policy is in place & Poor & $2.7 \pm 1.9$ & $2.5 \pm 1.8$ & 0.95 \\
\hline 35 & Improved packaging of slaughtered birds & Poor & $2.7 \pm 1.9$ & $6.3 \pm 2.7$ & 0.28 \\
\hline 36 & Hands washing after slaughter & Poor & $91.9 \pm 3.2$ & $17.5 \pm 4.3$ & $<0.0001$ \\
\hline 37 & Claims of hands disinfection after slaughter & Very poor & 0 & $10.0 \pm 3.4$ & 0.005 \\
\hline
\end{tabular}

Significant $P$ values are indicated in bold fonts. 
Table 2. Facility-related biosecurity

\begin{tabular}{|c|c|c|c|c|c|}
\hline s/no. & Facility-related biosecurity checklists & $\begin{array}{c}\text { Broad overview } \\
\text { of compliance at } \\
\text { LBM levels, } \\
\text { Nigeria* }\end{array}$ & $\begin{array}{l}\text { Nigerian LBM Compliance } \\
\text { level } \pm \text { SE }(\%)^{* *}\end{array}$ & $\begin{array}{l}\text { Egyptian LBM Compliance } \\
\text { level } \pm \text { SE }(\%)^{* * *}\end{array}$ & P-value \\
\hline 1 & $\begin{array}{l}\text { Location of market is appropriate to prevent/reduce human } \\
\text { contacts }\end{array}$ & Poor-very poor & $5.4 \pm 2.7$ & $20.0 \pm 4.5$ & $<0.01$ \\
\hline 2 & Fencing and gates around the market & Very poor & $5.4 \pm 2.7$ & $5 \pm 2.5$ & 0.93 \\
\hline 3 & Poultry market separated from other stands & Poor & $13.5 \pm 4.0$ & $6.3 \pm 2.7$ & 0.14 \\
\hline 4 & Garbage disposal services & Poor-very poor & $6.8 \pm 2.9$ & $2.5 \pm 1.7$ & 0.21 \\
\hline 5 & Segregation of customers and birds & Very poor & $1.4 \pm 1.4$ & $2.5 \pm 1.7$ & 0.6 \\
\hline 6 & Availability of cold chain & Very poor & $2.7 \pm 1.9$ & $3.8 \pm 2.1$ & 0.7 \\
\hline 7 & Quarantine for sick birds & Very poor & 0 & $2.5 \pm 1.7$ & 0.17 \\
\hline 8 & Facilities for culling birds & Very poor & $2.7 \pm 1.9$ & $3.8 \pm 2.1$ & 0.7 \\
\hline 9 & Presence of a laboratory in the LBM & Very poor & 0 & $3.8 \pm 2.1$ & 0.09 \\
\hline 10 & Presence of an incinerator in the LBM & Very poor & $1.4 \pm 1.4$ & $3.8 \pm 2.1$ & 0.34 \\
\hline 11 & Disinfection facilities for trucks & Very poor & 0 & $5 \pm 2.5$ & 0.05 \\
\hline 12 & Reduce number of birds/unit space in cages & Poor-good & $6.8 \pm 2.9$ & $5 \pm 2.5$ & 0.66 \\
\hline 13 & Floor and walls are easy to clean & Very poor & $4.1 \pm 2.3$ & $5.0 \pm 2.5$ & 0.76 \\
\hline 14 & Presence of drains on the floor & Very poor & $5.4 \pm 2.7$ & $5.0 \pm 2.5$ & 0.93 \\
\hline 15 & Availability of clean water & Poor-good & $6.8 \pm 2.9$ & $2.5 \pm 1.8$ & 0.21 \\
\hline 16 & Availability of hot water & Poor & 0 & $3.8 \pm 2.1$ & 0.09 \\
\hline 17 & Availability of toilets & Very poor & $6.8 \pm 2.9$ & $2.5 \pm 1.8$ & 0.21 \\
\hline 18 & Access to facility to wash hands and shoes & Poor & $6.8 \pm 2.9$ & $3.8 \pm 2.1$ & 0.41 \\
\hline 19 & Access to facility to disinfect hands and shoes & Very poor & 0 & $6.3 \pm 2.7$ & $\mathbf{0 . 0 3}$ \\
\hline 20 & Availability of storage facilities & Poor & $4.1 \pm 2.3$ & $3.8 \pm 2.1$ & 0.94 \\
\hline 21 & Enclosure to prevent escape & Good & $36.5 \pm 5.6$ & $22.5 \pm 4.7$ & 0.06 \\
\hline 22 & Water delivery system in place in the market & Poor & $2.7 \pm 1.9$ & $3.8 \pm 2.1$ & 0.7 \\
\hline 23 & Food delivery system in place in the market & Poor & $1.4 \pm 1.4$ & $2.5 \pm 1.8$ & 0.6 \\
\hline 24 & Availability of processing facilities & Poor-good & $5.4 \pm 2.7$ & $2.5 \pm 1.8$ & 0.36 \\
\hline
\end{tabular}

Significant $P$ values are indicated in bold fonts. 


\section{Compliance with tools and equipment-related biosecurity}

Biosecurity compliance scores for these items were generally below the acceptable levels with few exceptions (Table 3). For compliance with routine cleaning of cages $(P=0.0005)$, cleaning of equipments used for slaughtering $(P<0.0001)$ and protective materials worn by slaughter/processing persons $(P<0.0001)$, The LBMs in Nigerian performed better than the Egyptian LBMs but the markets in Egypt outperformed the Nigerian LBMs in the disinfection of equipments used for slaughtering $(P=0.02)$ (Table 3$)$.

\section{Logistic regression for risk factors analysis}

Based on the cut off set for Tolerance and VIF, the final model is free from instability. A total of sixty one (61) infected LBMs and ninety four (94) non-infected (control) LBMs were identified and confirmed by laboratory tests from Nigeria and Egypt. Univariable logistic regression on the sixty eight (68) variables were analysed for case and control (biological plausibility), magnitude of association and statistical significance at $\mathrm{p} \leq 0.20$ ( Supplementary Table 1 ). Thirty of the sixty eight variables yielded $p$-values $\leq 0.20$ and were subsequently imputed into the multivariable analyses. For the multivariable logistic regression, the variables: wild animals traded in the market $(\mathrm{OR}=34.90)$ and claims of hand disinfection after slaughter $(\mathrm{OR}=31.16)$ were significant risk factors while mandatory routine disinfection of LBMs, hands washing after slaughter and fencing and gates around the LBMs were plausible protective factors with significant association with HPAI H5N1 viral infection in LBMs in Nigeria and Egypt $(p \leq 0.05)$ (Table 4. 
Table 3. Tools and equipment-related biosecurity

\begin{tabular}{|c|c|c|c|c|c|}
\hline s/no. & Tools and equipment-related biosecurity checklist & $\begin{array}{c}\text { Broad } \\
\text { overview of } \\
\text { compliance at } \\
\text { LBM levels, } \\
\text { Nigeria* }\end{array}$ & Compliance level $\pm \mathrm{SE}(\%)^{* *}$ & $\begin{array}{c}\text { Egyptian LBM } \\
\text { Compliance level } \pm \text { SE } \\
(\%)^{* *}\end{array}$ & P-value \\
\hline 1 & Improved cages present in the market & Very poor & $4.1 \pm 2.3$ & $5.0 \pm 2.5$ & 0.76 \\
\hline 2 & Cleaning of cages done routinely & Poor & $51.4 \pm 5.9$ & $25 \pm 4.9$ & 0.0005 \\
\hline 3 & Disinfection of cages done routinely & Poor & $5.4 \pm 2.7$ & $6.3 \pm 2.7$ & 0.81 \\
\hline 4 & Disinfection of shared equipments & Poor & $1.4 \pm 1.4$ & $3.8 \pm 2.1$ & 0.34 \\
\hline 5 & Cleaning of equipments used for slaughtering & Poor & $79.7 \pm 4.7$ & $10.0 \pm 3.4$ & $<0.0001$ \\
\hline 6 & Disinfection of equipments used for slaughtering & Very poor & 0 & $7.5 \pm 3.0$ & $\mathbf{0 . 0 2}$ \\
\hline 7 & Protective materials worn by slaughter/processing persons & Very poor & $41.9 \pm 5.8$ & $12.5 \pm 3.7$ & $<0.0001$ \\
\hline
\end{tabular}

Significant $P$ values are indicated in bold fonts. 
Table 4. Multivariable analyses of variables associated with Biosecurity Compliance Level, Live Bird Markets, Nigeria and Egypt

\begin{tabular}{|c|l|c|c|c|c|}
\hline S/no. & Variables & Odd Ratio & SE & $\boldsymbol{P}$ values & 0.01 \\
\hline 1 & Wild animals traded in the market & 34.90 & 31.21 & $0.05-201.40$ \\
\hline 2 & Mandatory routine disinfections of the market & 0.13 & 0.06 & 0.00 & $0.05-0.33$ \\
\hline 3 & Fencing and gates around the market & 0.02 & 0.03 & 0.01 & $0.00-0.32$ \\
\hline 4 & Hands washing after slaughter & 0.41 & 0.19 & 0.05 \\
\hline 5 & Claims of hand disinfection after slaughter & 31.16 & 48.42 & $0.17-1.01$ \\
\hline
\end{tabular}




\section{Discussion}

Our work has confirmed that compliance with biosecurity measures in the Nigerian and Egyptian LBMs remains generally poor despite huge resource allocations, intense efforts and previous trainings conducted to support biosecurity implementation in these countries. Whereas LBM operators claimed to be practicing biosecurity measures, partial compliance were noticed in many of the operators shops. Pagani et al., (2008) have previously concluded that some biosecurity measures were poorly implemented while others were relatively well implemented in the Nigeria LBMs; our quantitative assessment supported the same assertion. However, because partial implementation and half-hearted compliance with biosecurity will limit the effort to control and eradicate outbreaks of rapidly spreading transboundary animal disease like HPAI H5N1, the continued endemicity of HPAI H5N1 and other influenza viruses in Egypt, as well as the resurgence of HPAI H5N1 in some other African countries may continue for the foreseeable future. Influenza viruses may persist in the LBM environment for weeks (Vong et al., 2008) and LBMs are suitable environments for potential virus reassortment (Nguyen et al., 2005; Kung et al., 2003; Cardona et al., 2009; Santhia et al., 2009; Wan et al., 2011, FAO, 2013; Lockhart et al., 2015) and are known sources of human and animal infection (Cardona et al., 2009; Santhia et al., 2009; Wan et al., 2011). In our study, approximately $39.4 \%$ of the surveyed markets were confirmed as infected.

Whereas three variables were protective for reducing the risk of infection of LBMs with the H5N1 virus including the mandatory routine disinfection of LBMs, hands washing after slaughter and traceability of origin of birds being sold in the LBMs, and previous workers have concluded similarly (Trock et al., 2008; Zhou et al., 2015), claims of hand disinfection after slaughter was surprisingly a strong risk factors. However, our field evaluations revealed that clear differences existed between the knowledge and applications of biosecurity implementation or hand disinfection (Conan et al., 2012; Saaan et al., 2012). Many of the LBM operators utilise minimally applied or over-diluted sodium 
hypochlorite (bleach), chloroxylenol, halogenated phenols and phenolics, chlorhexidine and other such antiseptics and disinfectants. In addition, the over-exposure of such mixed chemicals to direct sunlight or overnight storage rendered them ineffective. In other cases, hands were not thoroughly cleaned before the application of hand disinfectants. The above may explain why a claim of hand disinfection was a risk factor rather than a protective factor for infection of LBMs with HPAI H5N1 virus.

The sale of wild animals and birds in the market was also a significant risk for infection of LBMs with HPAI H5N1 virus. In most part of Africa, wild animals and birds are trapped and delivered at the live animal markets without quarantine, routine health check and welfare evaluation (Abdelwhab et al., 2010, Lee et al., 2010), It is highly likely that some of these animals that are of different species may have been exposed to low-grade influenza infection or are reservoir of infections, and there is possibility of shedding the virus and contaminating the LBMs environment (Cardona et al., 2009, CDC, 2015). It becomes mandatory that regulations should be made concerning zoo-sanitary measures and where these exist, implementation to guide the sale of wild birds and animals in the LBMs in Africa must be ensured.

Although biosecurity trainings have been implemented in the LBMs in Nigeria and Egypt during past outbreaks of HPAI H5N1, LBM operators still adhere poorly to hygiene and health. Circumstantial evidence pointed to the fact that the level of literacy may influence adherence to biosecurity compliance, previous studies have confirmed that literacy levels affect human behaviour with consequent effect on knowledge of HPAI and biosecurity (Abbate et al., 2006, Barennes et al., 2007, Fasina et al., 2009, Kuo et al., 2011, Yu et al., 2013). Intensive and reinforced training, as well as motivation for adherence to biosecurity will be required in LBMs to ensure reduction in burdens of influenza viruses (Magalhaes et al., 2010; Kuo et al., 2011; Manabe et al., 2012; Kurscheid et al., 2015).

In view of the fact that the LBMs systems' adherence to compensation mechanism for culled birds was poorly implemented in both countries, it is recommended that a carefully structured 
compensation system with regular options for review should be in place in African countries. It has been confirmed that compensation encourages cooperation of LBM operators and other role players and supports voluntary reportage of outbreaks (Alders et al., 2009; Hunter et al., 2014). To reduce financial losses, the LBM operators will rapidly sell sick poultry with implications for transmission of infection. However, compensation mechanism should be implemented with market reality as both under-compensation and overcompensation have produced unintended consequences that negatively affected animal disease control effort (World Bank, 2006; Mc Leod et al., 2016).

While Pagani et al (2008) have recommended that there's a need for redesigning of LBMs in Nigeria, the poorly-designed markets continue to exist in Nigeria and Egypt (Anonymous, 2008; Fasina et al., 2016) with implications for human health due to very close human-animal contacts. Currently, most LBMs are located within a much bigger general markets, in street corners in human locations and close to abattoir where poultry and other animals are slaughtered. We re-emphasise the need to put in place closed LBMs with infrastructures that support biosecurity compliance in countries within Africa where such is presently lacking (Kirunda et al., 2014). Although the development partners and international organisations may play supportive roles in the institutionalisation of these developments, it remains the primary roles of the African government to implement the building of such facilities.

We observed that compliance to some biosecurity items was better than some others, for example, hand washing, cleaning of equipment used for slaughtering and cleaning of cages. Whether this observation is due to previous biosecurity training given or is purely associated with personal protection associated with the human food chain was not investigated. Kurscheid et al., (2015), and other workers have stated that unless cleaning is thorough enough to remove all organic matters and disinfection is effective to penetrate and reach the microbes, transmission of the HPAI H5N1 infection cannot be prevented (Kilpatrick et al., 2006; Yee et al., 2008).

Because most of the policy and regulation-related biosecurity as well as facility-related biosecurity were poorly adhered to, we advocated a need for more veterinary infrastructures and services in African LBMs to monitor traceability, regulate traffic in live poultry, assess birds both pre-mortem 
and post-mortem in the LBMs (Magalhaes et al., 2010) and is correlated with formal education/training, which is in consonance with findings of Kuo et al., (2011) and Manabe et al., (2012).

Overall, the weekly LBMs performed better than the daily LBMs in terms of policy and regulations, facility, and tools and equipment-related biosecurity. It is possible that the reduced frequency of operations in the LBMs and rest days played roles in this observation (Fournie et al., 2011; Zhou et al., 2015).

In conclusion, we have confirmed that the roles of poultry traders, collectors, vendors and other LBM operators remain crucial to reducing the persistence, transmission and circulation of avian influenza viruses through increased biosecurity standards at poultry markets (Desvaux et al., 2011, Sims, 2012, Fourmie et al., 2013). In addition, operators in the LBMs are at risk of infection with H5N1 virus due to their daily contact with birds, and they can inadvertently transmit the HPAI virus to birds from market. The use of participatory epidemiology using multidisciplinary task team is highly recommended to enable the LBM operators adopt biosecurity measures as own initiative. Government legislation should include bottom-up approach and surveillance (active, passive and risk-based) and sero-monitoring should be a routine exercise at the LBMs. 


\section{References}

Abbate, R., Di Giuseppe, G., Marinelli, P., Angelillo, I.F., 2006. Knowledge, attitudes, and practices of avian influenza poultry workers, Italy. Emerg Infect Dis. 12, 1762-1765.

Abdelwhab, E. M., Selim, A.A, Arafa A., Galal, S., Kilany, W.H., Hassan., M.K., et al. 2010. Circulation of Avian Influenza H5N1in Live Bird Markets in Egypt. Avian Diseases Digest; 54(2):911-4. 12.

Alders, R., Bagno, 1.B., Brum, E., Lubis, A.S., Young, M.P., 2009. Continuing Education in the prevention and control of HPAI: a case study on Indonesia. World's Poult Sci J. 65: 529531.

Anonymous, 2008. The Development of Live Bird Markets in Nigeria. AICP - Animal Health Component of the AvianInfluenza Control \& Human Pandemic Preparedness and Response Project. Oscar Agricultural Consultants Limited.Available online at: http://www.aicpnigeria.org/documents/DevelopmentofLiveBirdMarkets.pdf (accessed on 15 September, 2015).

Barennes, H., Martinez-Ausse, 1.B., Vongphrachanh, P., Strobel, M., 2007. Avian influenza risk perceptions, Laos. Emerg Infect Dis. 13(7): 1126-1128.

Brown, M., Moore, L., McMahon, B., Powell, D., etal., 2015. Constructing Rigorous and Broad Biosurveillance Networks for Detecting Emerging Zoonotic Outbreaks. PLoS ONE 10(5):e0124037.doi:10.1371/journal.pone.012403

Cardona, C., Yee, K., Carpenter, T., 2009. Are live bird markets reservoirs for avian influenza?

Poult Sci. 88(4):856-859.doi:10.3382/ps.2008-00338.

http://ps.oxfordjournals.org/content/88/4/856.full

CDC (Centre for Disease Control and Prevention), 2015. Avian Influenza in birds. Avian influenza in wild birds CDC 24/7 http://www.cdc.gov/flu/avianflu/avian-in-birds.htm 
Conan, A., Goutard, F. L., Sorn, S., Vong, S., 2012. Biosecurity measures for backyard poultry in developing countries: a systematic review. BMC Veterinary Research 8:240. DOI:

$$
10.1186 / 1746-6148-8-240
$$

Desvaux, S., Grosbois, V., Pham, T.T.H., Fenwick, S., et al., 2011. Risk Factors of Highly Pathogenic Avian Influenza H5N1 Occurrence at the Village and Farm Levels in the Red River Delta Region in Vietnam. Transbound Emerg Dis. 58(6): 492-502 . doi:10.1111/j.1865-1682. 2011.01227.x.

ElMasry, I., El Sheikh, H., Abdelnabi, A., Saad, A., Arafa, A., Fasina, F.O., Lubroth, J., Jobre, Y.M., 2015. Avian influenza H5N1 surveillance and its dynamics in poultry in live bird markets, Egypt. Transbound Emerg Dis. doi:10.1111/tbed.12440.

FAO, 2013. Mapping Influenza A (H5N1) virus transmission pathways and critical control points in Egypt. Animal Production and Health Working Paper No. 11. Rome, Italy. Available at: http://www.fao.org/docrep/017/i3272e/i3272e.pdf. Accessed 08 March 2016.

FAO, 2015. H5N1 HPAI spread in Nigeria and increased risk for neighbouring countries in West Africa. EMPRES Animal Health@FAO.ORGWWW.FAO.ORG/AG/EMPRES.HTML Vol. $32,1-8$

Fasina, F.O., Bisschop, S.P.R., Ibironke, A.A., Meseko, C.A., 2009. Avian Influenza Risk Perception among Poultry Workers, Nigeria. Emerg Infect Dis. 15(4):616617.doi:10.3201/eid1504. 070159.

Fasina, F.O., Rivas, A.L., Bisschop, S.P.R., Stegeman, A.J., Hernandez, J.A., 2011. Identification of risk factors associated with highly pathogenic avian influenza H5N1 virus infection in poultry farms, in Nigeria during the epidemic of 2006-2007. Prev Vet Med. 98:204208.doi:10.1016/j. prevetmed.2010.11.007.

Fasina, F.O., Njage, P.M.K., Ali, A.M.M., Yilma, J.M., Bwala, D.G., Rivas, A.L., Stegemen, A.J., 2016. Development of Disease specific, Context specific Surveilance models: Avian 
Influenza (H5N1)- Related Risks and Behaviours in African Countries. Zoonoses Public Health 63, 20-33.

Fournié, G., Guitian, F.J., Mangtani, P., Ghani A. C., 2011. Impact of the implementation of rest days in live bird markets on the dynamics of H5N1 highly pathogenic avian influenza. J Roy Soc Interface 8(61), 1079-1089. doi:10.1098/rsif.2010.0510.

Fournié, G., Guitian, J., Desvaux, S.,Cuong, V.C., Dung, D.H., etal., 2013. Interventions for avian influenza A (H5N1) risk management in live bird market networks. PNAS 110 (22):91779182.doi: 10.1073/pnas.1220815110.

Hosmer, D.W., Lemeshow, S., 1989. Logistic regression for matched case-control studies. In: Hosmer, D.W., Lemeshow, S. (Eds.), Applied Logistic Regression. Wiley, New York, pp. $187-215$.

Hunter, C., Birden, H.H., Toribio, J.A., Booy, R., Abdurrahman. M., AmbarawatiI, G.A.A., et al., 2014. Community preparedness for highly pathogenic avian influenza on Bali and Lombok, Indonesia. Rural and Remote Health. 14: 2772.

Indriani, R., Samaan, G., Gultom, A., Loth, L., Irianti, S., Indryani, S., et al., 2010. Environmental sampling for avian influenza virus A (H5N1) in live-bird markets, Indonesia.Emerg. Infect. Dis. 16(12): 1889-95

Joannis, T., Lombin, L.H., DeBenedictis, P., Cattoli, G., Capua, I., 2006. Confirmation of H5N1 avian influenza in Africa. Vet Rec. 158:309-310.

Joannis, T.M., Meseko, C.A., Oladokun, A.T., Ularamu, H.G et al., 2008. Se ro lo g i c a n d vi rolog ic surveillance of avian influenza in Nigeria, 2006-7. EUROSURV. Vol . 13(42)· www.eurosurveillance.org

Kilpatrick, A.M., Chmura, A.A., Gibbons, D.W., Fleischer, R.C., Marra, P.P., Daszak, P., 2006. Predicting the global spread of H5N1 avian influenza. Proc Nat Acad Sci. (USA) 103(51): $19368-73$ 
Kirunda, H., Kibuuka, H., Byarunhanga, A., Nworozi, E., Bwogi, J., Luswa, 1., 2014. Poor biosecurity in Live bird markets in Uganda: A potential risk for highly pathogenic avian influenza outbreak in poultry and spread to humans. Int, J. Pub Hlth Epid. 3(9) 067-074. www.internationalscholarsjournal.org .

Kung, N.Y., Guan, Y., Perkins, N.R., Bissett, L., Ellis, T., Sims, L., et al., 2003. The impact of a monthly rest day on avian influenza virus isolation rates in retail live poultry markets in Hong Kong. Avian Dis 47(3): 1037-1041.

Kuo, P.C., Huang, J.H., Liu, M.D., 2011. Avian influenza risk perception and preventive behaviour among traditional market workers and shoppers in Taiwan: Practical implications for prevention. PLoS ONE 6(9): e24157.doi:10.1371/journal.pone.0024157.

Kurscheid, J., Millar, J., Abdurrahman, M., Ambarawati, I.G.A., Suadnya, W., Yusuf, R.P., et al. 2015. Knowledge and Perceptions of Highly PathogenicAvian Influenza (HPAI) among Poultry Traders in Live Bird Markets in Bali and Lombok, Indonesia. PLoS ONE 10 (10): e0139917. doi:10.1371/journal.pone.0139917

Lee, H.J., Kwon, J.S., Lee, D.H., Lee, Y.N., Youn, H.N., Lee, Y.J., et al., 2010. Continuing Evolution and Interspecies Transmission of Influenza Viruses in Live Bird Markets in Korea. Avian Dis. 2010;54:738-748.

Lockhart, C. , Pittiglio, C., Ingabire, C., Pinto, J., Bleasdadale, K.., et al., 2015. H5N1 HPAI spread in Nigeria and increased risk for neighbouring countries in West Africa. Vol. 32 Available at: .http://www.fao.org/3/a-i4561e.pdf. Accessed 07 March 2016.

Magalhaes, R.J.S., Ortiz-Palaez, A., Thi, K.L.L., Dinh, H.Q., Otte, J., Pfeiffer, D.U., 2010. Associations between attributes of live poultry trade and HPAI H5N1 outbreaks: a descriptiveand network analysis study in northern Vietnam. BMC Vet. Res. 6:10 http://www.biomedcentral.com/1746-6148/6/10

Manabe, T., Hanh, T.T., Lam, D.M., Van, D.T.H., Thuy, P.T.P, Huyen, D.T.T., et al., 2012. Knowledge, Attitudes, Practices and Emotional Reactions among Residents of Avian 
Influenza (H5N1) Hit Communities in Vietnam. PLoS ONE

7(10):e47560.doi:10.1371/journal.pone.0047560.

Mc Leod, A., Morgan, N., Prakash, A., Hinrichs, J., 2016. Economic and social impacts of avian influenza. Available at: http://www.fao.org/avianflu/documents/Economic-and-socialimpacts-of-avian-influenza-Geneva.pdf. Accessed 08 March 2016.

Metras, R., Stevens, K.B., Abdu, P., Okike, I., Randolph, T., Grace, D., et al., 2012. Identification of Potential Risk Factors Associated with Highly Pathogenic Avian Influenza Subtype H5N1 OutbreakOccurrence in Lagos and Kano States, Nigeria, During the2006-2007 Epidemics. Transbound Emerg Dis. 60(1):87-96. doi: 10.1111/j.1865-1682.2012.01322.x.

Nguyen, D.C., Uyeki, T.M., Jadhao, S., Maines, T., Shaw, M., Matsuoka, Y., et al.,2005. Isolation and characterization of avian influenza viruses, including highly pathogenic H5N1, from poultry in LBMs in Hanoi, Vietnam in 2001. J Virol 79(7),4201-4212.

Pagani, P., Abimiku, Y.J.E., Emeka-Okolie, W., 2008. Assessment of the Nigerian Poultry Market Chain to improve Biosecurity. FAO, Rome, Italy. Available at: .www.fao.org/3/aak778epdf. Accessed 15 July 2015.

Rivas, A.L., Chowell, G., Schwager, S.J., Fasina, F.O., Hoogesteijn, A.L., Smith, S.D., et al., 2010. Lessons from Nigeria: the role of roads in the geo-temporal progression of avian influenza (H5N1) virus. Epidemiol Infect. 138(2):192-8. doi: 10.1017/S0950268809990495.

Samaan, G., Hendrawati, F., Taylor, T., Pitona, T., Marmansari, D., Rahman, R., Lokuge, K., Kelly, P. M., 2012. Application of a healthy food markets guide to two Indonesian markets to reduce transmission of "avian flu". Bulletin of the World Health Organization 90:295-300. doi: 10.2471/BLT.11.090829

Santhia, K., Ramy, A., Jayaningsih, P., Samaan, G., Putra, A.A.G., Dibia, N., et al., 2009. Avian influenza A slearnedfromAH5N1infections in Bali province, Indonesia: a behavioral, virological and sero-epidemiological study. Influenza Other Respiratory Viruses. 3(3), 81-89. 
Sheta, B.M., Fuller, T.L., Larison, B., Njabo, K.Y., Ahmed, A.S., Harrigan, R., et al., 2014. Putative human and avian risk factors for avian influenza virus infections in backyard poultry in Egypt. Vet Microbiol. 168(1), 208-13.doi:10.1016/j.vetmic

Sims, L., 2007. Lessons learned from Asian H5N1outbreak control. Avian Dis. 51:174-181. doi: 10.1637/7637-042806r.1

Sims, L., 2012. Progress in Control of H5N1 Highly Pathogenic Avian Influenza and the Future for Eradication. Avian Dis. 56:829-835.

Trock, S.C. Gaeta, M. Gonzalez, A. Pederson, J.C. Senne, D.A., 2008. Evaluation of routine depopulation, cleaning, and disinfection procedures in the live bird markets, New York. Avian Dis, 52 (1), 160-162

Vong, S., Ly, S., Mardy, S., Holl, D., Buchy, P., 2008. Environmental contamination during influenza A virus (H5N1) outbreaks, Cambodia, 2006. Emerg Infect Dis 14(8), 1303-1305.

Wan, X., Dong, L., Lan, Y., Long, L., Xu, C., Zou, S., et al., 2011. Indications that Live Poultry Markets Are a Major Source of Human H5N1 Influenza Virus Infection in China. J. Virol. $85(24), 13432-13438$.

Wang, M., Di, B., Zhou, D.H., Zheng, B.J., Jing, H., Lin, Y.P., et al., 2006. Food markets with live birds as source of avian influenza. Emerg. Infect. Dis. 12: 1773-1775.

Webster, R.G.1., 2004. Wet markets-a continuing source of severe acute respiratory syndrome and influenza? Lancet. 17, 363(9404), 234-6.

World Bank (The), 2006. Enhancing control of highly pathogenic avian influenza in developing countries through compensation: Issues and good practice. Available at: http://web.oie.int/eng/avian_influenza/HPAI_Compensation_Final.pdf. Accessed on 08 March 2016 
World Organisation for Animal Health (OIE), 2015. Update on highly pathogenic avian influenza in animals (Type H5 and H7). Available from: URL: http://www.oie.int/animal-health-in-theworld/update-on-avian-influenza/2015/

World Organization for Animal Health (OIE), 2016. Update on Highly Pathogenic Avian Influenza in Animals (type H5 and H7). Available at: http://www.oie.int/en/animal-health-in-theworld/update-on-avian-influenza/2016/. Accessed on 03 March 2016.

Yee, K.S., Carpenter, E.T., Mize, S., Cardona, C.J., 2008. The Live Bird Market System and LowPathogenic Avian Influenza Prevention in Southern California, Case Report. Avian Dis., 52, 348-352.

Yu, Q., Liu, L., Pu, J., Zhao, J., Sun, Y., Shen. G., et al., 2013. Risk perceptions for avian influenza virus infection among poultry workers, China. Emerg Infect Dis. 19(2), 313-316.doi:10.3201/ eid1902.120251

Yupiana, Y., de Vlas, S.J., Adnan, N.M., Richardus, J.H., 2010. Risk factors of poultry outbreaks and human cases of H5N1 avian influenza virus infection in West Java Province,Indonesia. Int. J. Infect. Dis. 14(9): e800-e80

Zhou, X., Li, Y., Wang, Y., Edwards, J., Guo, F., Clements, A.C.A., 2015. The role of live poultry movement and live poultry market biosecurity in the epidemiology of influenza A (H7N9): A cross sectional observational study in four eastern China Province. J Infect. 71(4):470-9. doi: 10.1016/j.jinf.2015.06.012 


\section{Appendix A. Supplementary data}

Supplementary Table 1. Univariable analyses of risk factors associated with Biosecurity Compliance Level, Live Bird Markets, Nigeria and Egypt

\begin{tabular}{|c|c|c|c|c|c|c|c|c|c|}
\hline s/no. & 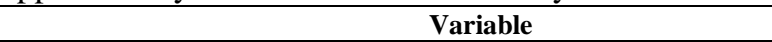 & Category & Case & Control & OR & $95 \% \mathrm{CI}$ & $P$ value & $\chi^{2}$ & Pvalue \\
\hline \multirow[t]{2}{*}{1} & Monitor activities in the market & No & 65 & 82 & 1.00 & Reference & NA & & \\
\hline & & Yes & 2 & 6 & 0.42 & $0.08 ; 2.15$ & 0.3 & 1.14 & 0.47 \\
\hline \multirow[t]{2}{*}{2} & Document movement of poultry into or from the market & No & 65 & 79 & 1.00 & Reference & NA & & \\
\hline & & Yes & 2 & 9 & 0.27 & $0.06 ; 1.29$ & 0.1 & 3.03 & 0.12 \\
\hline \multirow[t]{2}{*}{3} & Control movement of poultry into or from the market & No & 65 & 80 & 1.00 & Reference & NA & & \\
\hline & & Yes & 2 & 8 & 0.31 & $0.06 ; 1.50$ & 0.15 & 2.35 & 0.19 \\
\hline \multirow[t]{2}{*}{4} & Availability of specifications for vehicles carrying birds & No & 66 & 83 & 1.00 & Reference & NA & & \\
\hline & & Yes & 1 & 5 & 0.25 & $0.03 ; 2.21$ & 0.21 & 1.79 & 0.24 \\
\hline \multirow[t]{2}{*}{5} & Formal training of operators & No & 67 & 84 & 1.00 & Reference & NA & & \\
\hline & & Yes & 0 & 4 & - & - & - & 3.13 & 0.13 \\
\hline \multirow[t]{2}{*}{6} & Location of market is appropriate to prevent/reduce human contacts & No & 54 & 81 & 1.00 & Reference & NA & & \\
\hline & & Yes & 13 & 7 & 2.79 & $1.04 ; 7.43$ & 0.04 & 4.44 & 0.04 \\
\hline \multirow[t]{2}{*}{7} & Fencing and gates around the market & No & 66 & 81 & 1.00 & Reference & NA & & \\
\hline & & Yes & 1 & 7 & 0.18 & $0.02 ; 1.46$ & 0.07 & 3.25 & 0.14 \\
\hline \multirow[t]{2}{*}{8} & Poultry market separated from other stands & No & 63 & 77 & 1.00 & Reference & NA & & \\
\hline & & Yes & 4 & 11 & 0.44 & $0.13 ; 1.46$ & 0.18 & 1.86 & 0.17 \\
\hline \multirow[t]{2}{*}{9} & Ante and post-mortem inspection of birds & No & 67 & 83 & 1.00 & Reference & NA & & \\
\hline & & Yes & 0 & 5 & - & - & - & 3.93 & 0.07 \\
\hline \multirow[t]{2}{*}{10} & Access to para-veterinary services & No & 66 & 87 & 1.00 & Reference & NA & & \\
\hline & & Yes & 1 & 1 & 1.32 & $0.02 ; 104.64$ & 0.85 & 3.25 & 0.14 \\
\hline \multirow[t]{2}{*}{11} & Access to veterinary inputs & No & 66 & 84 & 1.00 & Reference & NA & & \\
\hline & & Yes & 1 & 4 & 0.32 & $0.03 ; 2.91$ & 0.31 & 1.14 & 0.39 \\
\hline \multirow[t]{2}{*}{12} & Garbage disposal services & No & 66 & 82 & 1.00 & Reference & NA & & \\
\hline & & Yes & 1 & 6 & 0.21 & $0.02 ; 1.76$ & 0.15 & 2.50 & 0.14 \\
\hline \multirow[t]{2}{*}{13} & All in-all out policy in the market & No & 67 & 83 & 1.00 & Reference & NA & & \\
\hline & & Yes & 0 & 5 & - & - & - & 3.93 & 0.07 \\
\hline \multirow[t]{2}{*}{14} & Segregation of customers and birds & No & 67 & 85 & 1.00 & Reference & NA & & \\
\hline & & Yes & 0 & 3 & - & - & - & 2.33 & 0.26 \\
\hline \multirow[t]{2}{*}{15} & Availability of cold chain & No & 67 & 83 & 1.00 & Reference & NA & & \\
\hline & & Yes & 0 & 5 & - & - & - & 3.93 & 0.07 \\
\hline \multirow[t]{2}{*}{16} & Quarantine for sick birds & No & 67 & 86 & 1.00 & Reference & NA & & \\
\hline & & Yes & 0 & 2 & - & - & - & 1.54 & 0.06 \\
\hline \multirow[t]{2}{*}{17} & Facilities for culling birds & No & 66 & 84 & 1.00 & Reference & NA & & \\
\hline & & Yes & 1 & 4 & 0.32 & $0.03 ; 2.91$ & 0.31 & 1.14 & 0.39 \\
\hline \multirow[t]{2}{*}{18} & Presence of a laboratory in the LBM & No & 67 & 85 & 1.00 & Reference & NA & & \\
\hline & & Yes & 0 & 3 & - & - & - & 2.33 & 0.26 \\
\hline \multirow[t]{2}{*}{19} & Presence of an incinerator in the LBM & No & 67 & 84 & 1.00 & Reference & NA & & \\
\hline & & Yes & 0 & 4 & - & - & - & 3.13 & 0.13 \\
\hline \multirow[t]{2}{*}{20} & Disinfection facilities for trucks & No & 67 & 84 & 1.00 & Reference & NA & & \\
\hline & & Yes & 0 & 4 & - & - & - & 3.13 & 0.13 \\
\hline \multirow[t]{2}{*}{21} & Reduce number of birds/unit space in cages & No & 65 & 81 & 1.00 & Reference & NA & & \\
\hline & & Yes & 2 & 7 & 0.36 & 0,$07 ; 1.77$ & 0.21 & 1.72 & 0.30 \\
\hline \multirow[t]{2}{*}{22} & Active poultry sellers association & No & 54 & 52 & 1.00 & Reference & NA & & \\
\hline & & Yes & 13 & 36 & 0.35 & 0.17 & 0.01 & 8.14 & 0.01 \\
\hline
\end{tabular}




\begin{tabular}{|c|c|c|c|c|c|c|c|c|c|}
\hline 23 & Separation of birds by species & No & 48 & 55 & 1.00 & Reference & NA & & \\
\hline & & Yes & 19 & 33 & 0.66 & $0.33 ; 1.31$ & 0.23 & 1.43 & 0.23 \\
\hline \multirow[t]{2}{*}{24} & Separation of birds by age/class & No & 64 & 78 & 1.00 & Reference & NA & & \\
\hline & & Yes & 3 & 10 & 0.37 & $0.10 ; 1.39$ & 0.13 & 2.35 & 0.15 \\
\hline \multirow[t]{2}{*}{25} & Control presence of wild birds & No & 50 & 85 & 1.00 & Reference & NA & & \\
\hline & & Yes & 17 & 3 & 9.63 & $2.69 ; 34.51$ & 0.0001 & 16.33 & 0.00 \\
\hline \multirow[t]{2}{*}{26} & Control presence of pests & No & 50 & 84 & 1.00 & Reference & NA & & \\
\hline & & Yes & 17 & 4 & 7.14 & $2.27 ; 22.42$ & 0.0002 & 14.09 & 0.00 \\
\hline \multirow[t]{2}{*}{27} & Other animals traded in the market & No & 33 & 17 & 1.00 & Reference & NA & & \\
\hline & & Yes & 34 & 71 & 0.25 & $0.12 ; 0.50$ & 0.0001 & 15.60 & 0.00 \\
\hline \multirow[t]{2}{*}{28} & Wild animals traded in the market & No & 44 & 84 & 1.00 & Reference & NA & & \\
\hline & & Yes & 23 & 4 & 12.50 & $4.08 ; 38.26$ & 0.0001 & 26.86 & 0.00 \\
\hline \multirow[t]{2}{*}{29} & Mandatory routine disinfections of the market & No & 42 & 27 & 1.00 & Reference & NA & & \\
\hline & & Yes & 25 & 61 & 12.50 & $3.90 ; 51.76$ & 0.0001 & 18.76 & 0.00 \\
\hline \multirow[t]{2}{*}{30} & Restriction of movement of operators from market to market & No & 67 & 82 & 1.00 & Reference & NA & & \\
\hline & & Yes & 0 & 6 & - & - & - & 4.75 & 0.04 \\
\hline \multirow[t]{2}{*}{31} & Floor and walls are easy to clean & No & 66 & 82 & 1.00 & Reference & NA & & \\
\hline & & Yes & 1 & 6 & 0.21 & $0.02 ; 1.76$ & 0.15 & 2.50 & 0.14 \\
\hline \multirow[t]{2}{*}{32} & Presence of drains on the floor & No & 66 & 81 & 1.00 & Reference & NA & & \\
\hline & & Yes & 1 & 7 & 0.18 & $0.02 ; 1.46$ & 0.07 & 3.25 & 0.14 \\
\hline \multirow[t]{2}{*}{33} & Availability of clean water & No & 66 & 83 & 1.00 & Reference & NA & & \\
\hline & & Yes & 1 & 5 & 0.25 & $0.03 ; 2.18$ & 0.21 & 1.83 & 0.23 \\
\hline \multirow[t]{2}{*}{34} & Availability of hot water & No & 67 & 85 & 1.00 & Reference & NA & & \\
\hline & & Yes & 0 & 3 & - & - & - & 2.33 & 0.26 \\
\hline \multirow[t]{2}{*}{35} & Availability of toilets & No & 66 & 82 & 1.00 & Reference & NA & & \\
\hline & & Yes & 1 & 6 & 0.21 & $0.02 ; 1.76$ & 0.15 & 2.50 & 0.14 \\
\hline \multirow[t]{2}{*}{36} & Access to wash hands and shoes & No & 66 & 81 & 1.00 & Reference & NA & & \\
\hline & & Yes & 1 & 7 & 0.18 & $0.02 ; 1.46$ & 0.07 & 3.25 & 0.14 \\
\hline \multirow[t]{2}{*}{37} & Access to facility to disinfect hands and shoes & No & 67 & 83 & 1.00 & Reference & NA & & \\
\hline & & Yes & 0 & 5 & - & - & - & 3.93 & 0.07 \\
\hline \multirow[t]{2}{*}{38} & Safe disposal of sick birds & No & 66 & 83 & 1.00 & Reference & NA & & \\
\hline & & Yes & 1 & 5 & 0.25 & $0.03 ; 2.21$ & 0.21 & 1.79 & 0.24 \\
\hline \multirow[t]{2}{*}{39} & Safe disposal of carcasses & No & 67 & 79 & 1.00 & Reference & NA & & \\
\hline & & Yes & 0 & 9 & - & - & - & 7.28 & 0.01 \\
\hline \multirow[t]{2}{*}{40} & Safe disposal of wastes & No & 65 & 80 & 1.00 & Reference & NA & & \\
\hline & & Yes & 2 & 8 & 0.31 & $0.06 ; 1.50$ & 0.15 & 2.35 & 0.19 \\
\hline \multirow[t]{2}{*}{41} & Good hygiene (proper cleaning and disinfection) in the market & No & 66 & 81 & 1.00 & Reference & NA & & \\
\hline & & Yes & 1 & 7 & 0.18 & $0.02 ; 1.46$ & 0.07 & 3.25 & 0.14 \\
\hline \multirow[t]{2}{*}{42} & Good hygiene (proper cleaning and disinfection) at slaughtering points & No & 66 & 83 & 1.00 & Reference & NA & & \\
\hline & & Yes & 1 & 5 & 0.25 & $0.005 ; 2.34$ & 0.18 & 3.25 & 0.14 \\
\hline \multirow[t]{2}{*}{43} & Disinfection of infrastructure and equipment & No & 66 & 81 & 1.00 & Reference & NA & & \\
\hline & & Yes & 1 & 7 & 0.18 & $0.02 ; 1.46$ & 0.07 & 3.25 & 0.14 \\
\hline \multirow[t]{2}{*}{44} & Disinfection of premises & No & 66 & 81 & 1.00 & Reference & NA & & \\
\hline & & Yes & 1 & 7 & 0.18 & $0.02 ; 1.46$ & 0.07 & 3.13 & 0.13 \\
\hline 45 & Alternative use of disinfectants & No & 67 & 84 & 1.00 & Reference & NA & & \\
\hline & & Yes & 0 & 4 & - & - & - & 4.56 & 0.03 \\
\hline
\end{tabular}




\begin{tabular}{|c|c|c|c|c|c|c|c|c|c|}
\hline 46 & Compensation mechanism in place for culled birds & No & 57 & 62 & 1.00 & Reference & NA & & \\
\hline & & Yes & 10 & 26 & 0.42 & $0.19 ; 0.94$ & 0.04 & 4.56 & 0.03 \\
\hline \multirow[t]{2}{*}{47} & Availability of storage facilities & No & 66 & 83 & 1.00 & Reference & NA & & \\
\hline & & Yes & 1 & 5 & 0.25 & $0.03 ; 2.21$ & 0.21 & 1.79 & 0.18 \\
\hline \multirow[t]{2}{*}{48} & Keeping of new arrivals separated from old stock & No & 66 & 83 & 1.00 & Reference & NA & & \\
\hline & & Yes & 0 & 5 & - & - & - & 3.93 & 0.05 \\
\hline \multirow[t]{2}{*}{49} & Enclosure to prevent escape & No & 53 & 57 & 1.00 & Reference & NA & & \\
\hline & & Yes & 14 & 31 & 0.49 & $0.23 ; 1.01$ & 0.05 & 3.79 & 0.05 \\
\hline \multirow[t]{2}{*}{50} & Improved cages present in the market & No & 66 & 82 & 1.00 & Reference & NA & & \\
\hline & & Yes & 1 & 6 & 0.21 & $0.02 ; 1.76$ & 0.15 & 2.50 & 0.14 \\
\hline \multirow[t]{2}{*}{51} & Water delivery system in place in the market & No & 66 & 84 & 1.00 & Reference & NA & & \\
\hline & & Yes & 1 & 4 & 0.32 & $0.03 ; 2.92$ & 0.31 & 1.14 & 0.39 \\
\hline \multirow[t]{2}{*}{52} & Food delivery system in place in the market & No & 67 & 85 & 1.00 & Reference & NA & & \\
\hline & & Yes & 0 & 3 & - & - & - & 2.33 & 0.26 \\
\hline \multirow[t]{2}{*}{53} & Cleaning of cages done routinely & No & 52 & 44 & 1.00 & Reference & NA & & \\
\hline & & Yes & 15 & 44 & 0.29 & $0.14 ; 0.59$ & 0.0005 & 12.30 & 0.00 \\
\hline \multirow[t]{2}{*}{54} & Disinfection of cages done routinely & No & 65 & 81 & 1.00 & Reference & NA & & \\
\hline & & Yes & 2 & 7 & 0.36 & $0.07 ; 1.77$ & 0.21 & 1.72 & 0.30 \\
\hline \multirow[t]{2}{*}{55} & Prohibition of sharing of cages and other equipment & No & 67 & 85 & 1.00 & Reference & NA & & \\
\hline & & Yes & 0 & 3 & - & - & - & 2.33 & 0.26 \\
\hline \multirow[t]{2}{*}{56} & Disinfection of shared equipments & No & 67 & 84 & 1.00 & Reference & NA & & \\
\hline & & Yes & 0 & 4 & - & - & - & 3.13 & 0.13 \\
\hline \multirow[t]{2}{*}{57} & Traceability of origin of birds being sold & No & 62 & 68 & 1.00 & Reference & NA & & \\
\hline & & Yes & 5 & 20 & 0.27 & $0.10 ; 0.77$ & 0.02 & 6.55 & 0.01 \\
\hline \multirow[t]{2}{*}{58} & Certification system in place for transport of birds & No & 67 & 86 & 1.00 & Reference & NA & & \\
\hline & & Yes & 0 & 2 & - & - & - & 1.54 & 0.51 \\
\hline \multirow[t]{2}{*}{59} & Rest period between batches of birds & No & 67 & 83 & 1.00 & Reference & NA & & \\
\hline & & Yes & 0 & 5 & - & - & - & 3.93 & 0.07 \\
\hline \multirow[t]{2}{*}{60} & Policy is in place for unsold birds & No & 67 & 85 & 1.00 & Reference & NA & & \\
\hline & & Yes & 0 & 3 & - & - & - & 2.33 & 0.13 \\
\hline \multirow[t]{2}{*}{61} & Availability of processing facilities & No & 66 & 83 & 1.00 & Reference & NA & & \\
\hline & & Yes & 1 & 5 & 0.25 & $0.03 ; 2.21$ & 0.21 & 1.79 & 0.33 \\
\hline \multirow[t]{2}{*}{62} & Live in-dead out policy is in place & No & 67 & 84 & 1.00 & Reference & NA & & \\
\hline & & Yes & 0 & 4 & - & - & - & 3.13 & 0.13 \\
\hline \multirow[t]{2}{*}{63} & Improved packaging of slaughtered birds & No & 64 & 84 & 1.00 & Reference & NA & & \\
\hline & & Yes & 3 & 4 & 0.98 & $0.21 ; 4.55$ & 0.98 & 0.00 & 1.00 \\
\hline \multirow[t]{2}{*}{64} & Cleaning of equipments used for slaughtering & No & 53 & 35 & 1.00 & Reference & NA & & \\
\hline & & Yes & 15 & 52 & 0.19 & $0.09 ; 0.39$ & $<0.0001$ & 22.12 & 0.00 \\
\hline \multirow[t]{2}{*}{65} & Disinfection of equipments used for slaughtering & No & 64 & 85 & 1.00 & Reference & NA & & \\
\hline & & Yes & 3 & 3 & 1.33 & $0.26 ; 6.80$ & 0.73 & 0.12 & 1.00 \\
\hline \multirow[t]{2}{*}{66} & Protective materials worn by slaughter/processing persons & No & 52 & 62 & 1.00 & Reference & NA & & \\
\hline & & Yes & 15 & 26 & 0.69 & $0.33 ; 1.43$ & 0.32 & 23.39 & 0.00 \\
\hline \multirow[t]{2}{*}{67} & Hands washing after slaughter & No & 46 & 26 & 1.00 & Reference & NA & & \\
\hline & & Yes & 21 & 62 & 0.19 & $0.10 ; 0.38$ & $<0.0001$ & 6.74 & 0.02 \\
\hline 68 & Claims of hand disinfection after slaughter & No & 60 & 87 & 1.00 & Reference & NA & & \\
\hline
\end{tabular}

